\title{
密封小線源療法施行前内分泌療法による前立腺体積縮小効果
}

\author{
独立行政法人国立病院機構東京医療センター泌沓器科1，同 放射線科2)

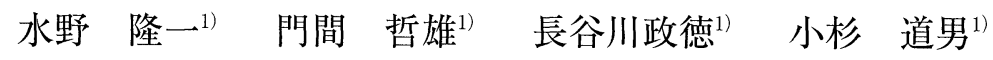 \\ 大橋 俊夫 ${ }^{22}$ 戸矢 和仁 $^{22}$ 萬 篤憲 ${ }^{2)}$ 斉藤 史郎 ${ }^{12}$

\section{INFLUENCE OF ANDROGEN DEPRIVATION THERAPY ON PROSTATE VOLUME \\ IN PATIENTS WITH PROSTATE CANCER UNDERGOING PROSTATE BRACHYTHERAPY WITH PERMANENT SEED IMPLANTATION}

\author{
Ryuichi Mizuno $^{1)}$, Tetsuo Monma ${ }^{1)}$, Masanori Hasegawa ${ }^{1)}$, Michio Kosugi ${ }^{1)}$ \\ Toshio Ohashi ${ }^{2)}$, Kazuhito Toya ${ }^{2)}$, Atsunori Yorozu ${ }^{2)}$ and Shiro Saito ${ }^{1)}$ \\ Departments of Urology ${ }^{1)}$ and Radiology ${ }^{2)}$, National Tokyo Medical Center
}

(Objective) Enlarged prostate often causes pubic arch interference during needle insertion on transperineal interstitial permanent prostate brachytherapy. Pre-treatment hormonal therapy is necessary for downsizing the prostate gland in such cases. The degree of prostate downsizing with antiandrogen treatment before iodine 125 permanent seed implant brachytherapy and its relation to clinical as well as pathological parameters were assessed.

(Methods) From September 2003 to March 2005, 110 patients underwent permanent seed implantation and 86 patients of all received antiandrogen depriviation prior to the treatment at our institute. Prostate volume was measured using transrectal ultrasound at the time of cancer diagnosis and before the seed implant. Correlations between prostate downsizing and clinical as well as pathological parameters were evaluated.

(Results) Mean percent volume of the prostate after the size reduction with average of 6.0 months antiandrogen monotherapy, 7.7 months LHRH agoniost and 8.2 months maximum androgen blockage (MAB) was $83 \%, 63 \%$, and $60 \%$, respectively. Mann-Whitney U test revealed that the degree of prostate downsizing is significantly correlated with the prostate volume in patients with prostate cancer utilizing LHRH agonists.

(Conclusions) Antiandrogen monotherapy can be an alternative for prostate downsizing before interstitial brachytherapy. Utilizing LHRH agonists or MAB is recommended for cases with larger gland volume.

Key words : prostate cancer, brachytherapy, prostate volume

要旨：(目的）前立腺癌に対する I-125 密封小線源療法施行前の内分泌療法による前立腺体積の縮小率 に関しての検討を行った.

(対象と方法) 当院において，2003 年 9 月より 2005 年 3 月の間に I-125 密封小線源療法が施行された 110 例を対象とした，前立腺癌診断時㧍よび密封小線源療法施行前の前立腺体積を経直腸的超音波検查 により測定し，それぞれの前立腺縮小率（縮小後の縮小前の体積に対する割合）を計算した．さらに前 立腺縮小率と病理組織学的因子, 臨床因子との関連について検討した.

(結果) 抗アンドロゲン剂単独群では縮小率は平均 83\%, LHRH アゴニスト単独群では平均 $63 \%$ であ り, LHRH アゴニストと抗アンドロゲン剂の併用群では平均 $60 \%$ であった. いずれも無治療群と比較す ると縮小率に有意差が認められた. LHRH アゴニストを投与した 53 例において, Mann-Whitney U 検定 では前立腺縮小率と前立腺体積との間に有意な相関が認められた $(\mathrm{p}<0.0001)$. 単回帰分析においても前 
立腺縮小率と内分泌療法前の前立腺体積との間にのみ有意な相関が認められた（ $\mathrm{p}=0.0016 ）$.

(結論）小線源療法施行前の抗アンドロゲン剂単独投与の前立腺体積縮小のための手段としての有効 性が示された. 前立腺体積の大きな症例では LHRH アゴニストの単独投与あるいは抗アンドロゲン剤と の併用によってより確実な前立腺体積の縮小が期待できると考えられた.

キーワード : 前立腺癌, 密封小線源療法, 前立腺体積

\section{緒言}

前立腺癌に対するヨウ素 125 (I-125) シード線源永久 挿入による密封小線源療法は, 患者にとって利点の多 い優れた治療法であると考えられている1). 米国にお いては限局性前立腺癌の治療として根治的前立腺全摘 除術の占める割合が減少し，それに伴い小線源療法が 行われる頻度が増加してきている2). 本邦においても 2003 年 9 月より本治療が開始され, 現在全国へ普及し ている ${ }^{344)}$. 本治療法の施行に際し, 前立腺体積が大き い症例では，恥骨弓による前立腺辺縁部へのシードの 挿入困難や体内留置放射能の増大といった問題が生じ る. そのため, 小線源療法に先立ち, 前立腺体積の縮 小を目的とした内分泌療法が施行されることがあ $る^{556)}$. 前立腺肥大症に対する内分泌療法が前立腺体積 を縮小させることは以前から知られており ${ }^{7 / 8)}$, 同様 に, 限局性前立腺癌に対する内分泌療法によっても前 立腺体積の縮小が確認されている 腺体積の縮小率が限局性前立腺癌の治療に際して有用 な情報を与えることは少ないと考えられてきた。 しか しながら, 小線源療法の導入により, 前立腺体積によっ て治療の選択肢が変わることもあるため, 内分泌療法 による前立腺縮小率が注目されるようになってきてい る. 本研究においては, 密封小線源療法施行前の内分泌 療法による前立腺体積の縮小に関する検討を行った。

\section{対象・方法}

独立行政法人国立病院機構東京医療センターにおい て, 2003 年 9 月より 2005 年 3 月の間に前立腺癌に対 して I-125 密封小線源療法が施行された 279 例のう ち, 内分泌療法施行前後で前立腺体積の測定が可能で あった 86 例と内分泌療法を施行しなかった 24 例の計 110 例を対象とした．当院紹介受診時の経直腸的超音 波検査に際し，何らかの内分泌療法が行われている症 例はすべて検討から除外した. 全例で経直腸的針生検 が施行され, 認定病理医による病理診断が行われた. 前立腺体積 $40 \mathrm{ml}$ 以上を内分泌療法の適応としたが, 治療待機期間中に病勢の進行が危惧される症例や患者 からの希望がある場合には小線源療法予定日まで適宜 施行した．前立腺体積の測定は経直腸的超音波検查に
より行った.「前立腺縮小率 $=$ 小線源療法施行時の測定 值/内分泌療法施行前の測定值」によって計算した。内 分泌療法の相違によるそれぞれの前立腺縮小率を計算 し, 前立腺縮小率と病理組織学的因子, 臨床因子との 関連について検討した，統計学的検討には，MannWhitney U 検定と単回帰分析を用いた.

\section{結 果}

対象患者の背景因子を表 1 に示した。平均年齢 67.5 歳, 診断時平均血清 PSA 值は $9.9 \mathrm{ng} / \mathrm{ml}$, 平均生検陽性 コア率は $33.2 \%$, Gleason score 7 未満が 78 例, 7 が 30 例, 8 以上が 2 例であった. 65 例が I-125 密封小線源療 法単独によって治療され，45例が小線源療法と外照射 の併用によって治療された。

内分泌療法の内訳を表 2 に示した。無治療群が 24 例に対し, 抗アンドロゲン剂単独治療群は 33 例, 平均 施行期間 6.0 カ月であり, LHRH アゴニスト単独治療 群は 33 例，平均施行期間 7.7 カ月であった。 LHRH アゴニストと抗アンドロゲン剤の併用群は 20 例, 平均 施行期間 8.2 カ月であった. 抗アンドロゲン剂として フルタミド，ビカルタミドが投与され，LHRH アゴニ ストとして酢酸リュープロレリン, 酢酸ゴセレリンが 投与された. 抗アンドロゲン剂投与群の 1 例において, 肝機能障害を認め, 薬剤の変更を必要とした.

内分泌療法別による前立腺縮小率を図 1 に示した. 無治療群の平均前立腺縮小率 $98 \%$ に対し, 抗アンドロ ゲン剤単独群では $83 \%$ で, 無治療群との間に有意差が 認められた $(\mathrm{p}=0.0183) . \mathrm{LHRH}$ アゴニスト単独群では 平均縮小率 $63 \%$ であり，無治療群との間に有意差が認 められた $(\mathrm{p}<0.0001)$. 抗アンドロゲン剤単独群との間 においても有意差が認められた（p<0.0001）。 LHRH アゴニストと抗アンドロゲン剤の併用群では平均縮小 率 $60 \%$ であり, 無治療群と比較して有意差が認められ た $(\mathrm{p}<0.0001)$. 抗アンドロゲン剤単独群との間におい ても有意差が認められた $(\mathrm{p}<0.0001)$. しかしながら LHRH アゴニスト単独群との間には縮小率に有意差 は認められなかった。

LHRH アゴニストを投与した 53 例において，前立 腺縮小率と病理組織学的因子, 臨床因子との関連につ 
表 1 患者背景

\begin{tabular}{l|ll}
\hline PSA $(\mathrm{ng} / \mathrm{ml})$ & $9.9 \pm 5.7$ & $(1.1 \sim 30.0)$ \\
年齢 & $67.5 \pm 7.0 \quad(50 \sim 85)$ \\
生検陽性コア率 $(\%)$ & $33.2 \pm 21.1 \quad(7.1 \sim 100.0)$ \\
Gleason score & $<7 \quad 78$ \\
& $\geqq 7$ & 32 \\
\hline
\end{tabular}

表 2 内分泌療法の内訳

\begin{tabular}{l|c|c}
\hline \multicolumn{1}{c|}{ 内分泌療法 } & 症例 & 施行期間 (月) \\
\hline 無治療 & 24 & \\
抗アンドロゲン剂 & 33 & $6.0 \pm 2.5$ \\
LHRH アゴニスト & 33 & $7.7 \pm 7.1$ \\
LHRH アゴニスト+ & 20 & $8.2 \pm 2.3$ \\
抗アンドロゲン剂 & & \\
\hline
\end{tabular}

図 1 内分泌療法による前立腺縮小率

$*$ not significant $* * \mathrm{p}=0.0183$

$* * * \mathrm{p}<0.0001$

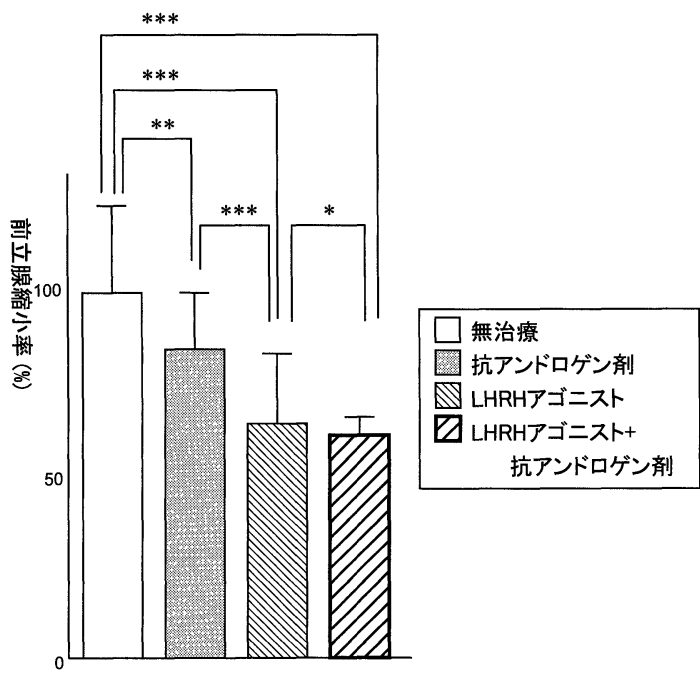

いて検討した（表 3). Mann-Whitney U 検定では前立 腺縮小率と内分泌療法施行前前立腺体積との間に有意 な相関が認められた $(\mathrm{p}<0.0001)$ ．前立腺縮小率と身 長，体重，BMI，年齢，PSA 值，内分泌療法施行期間， Gleason score，生検陽性コア率との間には有意な相関 は認められなかった，単回帰分析においても前立腺縮 小率と内分泌療法前前立腺体積との間にのみ有意な相 関が認められた $(p=0.0016)$ (図 2$)$.
表 3 LHRH アゴニスト投与群における前立腺縮小 率と病理組織学的因子, 臨床因子との関連

\begin{tabular}{l|c|c}
\hline \multicolumn{1}{c|}{ 検討項目 } & $\begin{array}{c}\text { correlation } \\
\text { analysis } \\
\text { (p value) }\end{array}$ & $\begin{array}{c}\text { simple regression } \\
\text { analysis } \\
\text { ( } \mathrm{p} \text { value })\end{array}$ \\
\hline 身長 & N.S. & \\
体重 & N.S. & \\
BMI & N.S. & \\
年齢 & N.S. & \\
内分泌療法前前立腺体積 & p < 0.0001 & $\mathrm{p}=0.0016$ \\
PSA & N.S. & \\
内分泌療法施行期間 & N.S. & \\
Gleason score & N.S. & \\
生検陽性コア率 & N.S. & \\
\hline
\end{tabular}

図 2 前立腺体積と前立腺縮小率

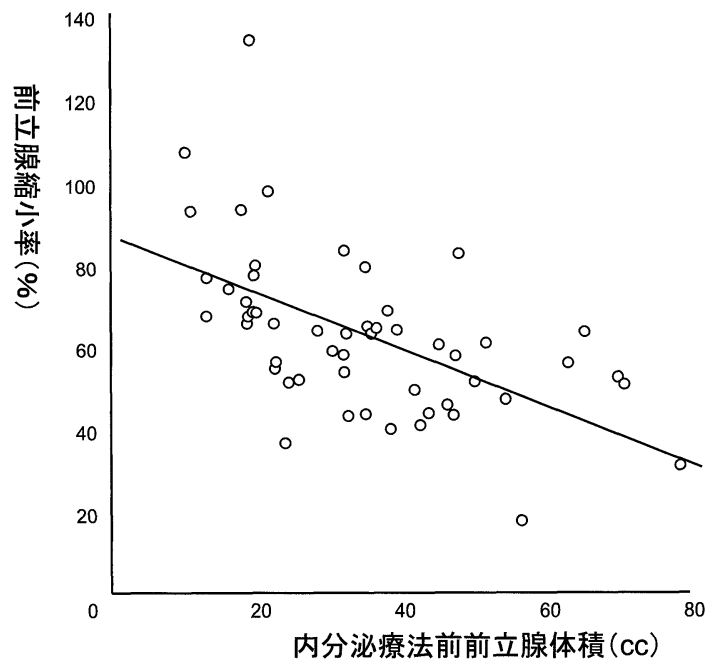

考察

日本泌尿器科学会, 日本放射線腫瘍学会, 日本医学 放射線学会の定める「シード線源による前立腺永久挿 入密封小線源治療の安全管理に関するガイドライン」 では，I-125 シード線源を前立腺内に挿入した場合，体 内残存放射能が $1,300 \mathrm{MBq}$ ，もしくは患者の体表面か ら $1 \mathrm{~m}$ 離れた位置における $1 \mathrm{~cm}$ 線量当量率が 1.8 $\mu \mathrm{Sv} / \mathrm{h}$ 以下のときに放射線管理区域から退出でき，退 院も可能となる，とされている ${ }^{10)}$. 現在までの経験か ら, 小線源単独治療の場合, 前立腺体積が $38 \mathrm{ml}$ を越え ると必要とする線源が多くなるため, $1,300 \mathrm{MBq}$ を超 える可能性があり, その場合には外照射を併用するか 
内分泌療法で体積を縮小させる必要が生じる ${ }^{314)}$ ．ま た, 前立腺体積が $40 \mathrm{ml}$ を越える場合には恥骨弓に阻 まれてシードの挿入が困難となる場合が多いため, 前 立腺体積の大きな症例に対する永久挿入密封小線源療 法の施行に際しては, 体積の縮小を目的として内分泌 療法を先行させる必要がある.

本研究においては, 抗アンドロゲン剤単独投与で前 立腺体積は約 $83 \%$ に縮小され, LHRH アゴニスト単 独投与あるいは抗アンドロゲン剂との併用で前立腺体 積は約 $60 \%$ 程度に縮小された.この結果から, 前立腺 体積が $45 \mathrm{cc}$ 程度であれば, 抗アンドロゲン剂単独投与 によっても小線源単独治療が可能となる程度までの体 積の縮小が期待できるが，それより大きな症例では LHRH アゴニストの投与が必要となると考えられた. 内分泌療法施行前の前立腺体積が $65 \mathrm{ml}$ 以上の症例で は, LHRH アゴニストと抗アンドロゲン剤との併用に よっても小線源単独治療は困難であると考えられた. 抗アンドロゲン剂単独投与はテストステロン産生を抑 制しないため男性性機能の温存が可能で, ホットフ ラッシュや体重増加などの副作用が少ないなどの報告 があり ${ }^{11)}$ ，患者の QOLを良好に維持できると考えら れる. 内分泌療法ごとの患者の QOL の確認は今後の 検討課題と思われた.

本研究においては, また, LHRH アゴニスト投与群 に扔ける前立腺縮小率と内分泌療法施行前の前立腺体 積との間に有意な相関が認められた. 回帰分析の結果 から, 内分泌療法施行前の前立腺体積が大きな症例ほ ど，LHRH アゴニスト投与による前立腺縮小率が大き いと考えられた．前立腺体積縮小率に関する現在まで の報告では, 前立腺体積に加えて施行期間が前立腺縮 小率の有意な予測因子であるといわれている612).こ れらの報告では内分泌療法施行期間が平均 3 カ月だっ たのに対し, 本研究の対象症例は治療待機期間の関係 で平均施行期間が $6 \sim 8$ 力月と長い症例だったため, 施 行期間が予測因子として残らなかったと思われる. 今 後は内分泌療法の適正な継続期間内の検討も必要と考 えられた。

\section{結 論}

小線源療法施行前の抗アンドロゲン剤単独投与は前 立腺体積縮小のための手段となりうることが示され た. 前立腺体積の大きな症例では LHRH アゴニストの 単独投与あるいは抗アンドロゲン剤との併用によって より確実な前立腺体積の縮小が期待できることが合わ せて示された.

\section{文献}

1) Ragde H, Elgamal AA, Snow PB, Brandt J, Bartolucci AA, Nadir BS, Korb LJ : Ten-year disease free survival after transperineal sonographyguided iodine-125 brachytherapy with or without 45-gray external beam irradiation in the treatment of patients with clinically localized, low to high Gleason grade prostate carcinoma. Cancer, 83, 989-1001, 1998.

2) Cooperberg MR, Lubeck DP, Meng MV, Mehta SS, Carroll PR: The changing face of low-risk prostate cancer : trends in clinical presentation and primary management. J Clin Oncol, 22, 2141-2149, 2004.

3）斉藤史郎：永久挿入密封小線源療法（brachytherapy). カレントテラピー, 22(9), 908-914,2004.

4）斉藤史郎：前立腺癌永久挿入密封小線源療法の実 際. 泌尿器外科, 17 (4), 285-291, 2004.

5) Wang H, Wallner K, Sutlief S, Blasko J, Russell K, Ellis W.: Transperineal brachytherapy in patients with large prostate glands. Int J Cancer, 90, 199$205,2000$.

6) Kucway R, Vicini F, Huang R, Stromberg J, Gonzalez J, Martinez A. : Prostate volume reduction with androgen deprivation therapy before interstitial brachytherapy. J Urol, 167, 2443-2447, 2002.

7) McConnell JD. : Androgen ablation and blockade in the treatment of benign prostatic hyperplasia. Urol Clin North Am, 17, 661-670, 1990.

8) Gormley GJ, Stoner E, Bruskewitz RC, ImperatoMcGinley J, Walsh PC, McConnell JD, Andriole GL, Geller J, Bracken BR and Tenover JS. : The effect of finasteride in men with benign prostatic hyperplasia. N Engl J Med, 327, 1185-1191, 1992.

9) Nishiyama T, Tomita $Y$, Takahashi K. : Influence of androgen deprivation therapy on volume of anatomic zones of prostate in patients with prostate cancer using magnetic resonance imaging. Urology, 63, 917-921, 2004.

10）シード線源による前立腺永久挿入密封小線源治療 の安全管理に関するガイドライン 第三版 日本 放射線腫場学会, 日本泌尿器科学会, 日本医学放射 線学会 平成 16 年 5 月 12 日改定.

11) Miyamoto H, Messing EM, Chang C.: Androgen deprivation therapy for prostate cancer : current status and future prospects. Prostate, 61, 332$353,2004$.

12) Whittington R, Broderick GA, Arger P, Malkowicz SB, Epperson RD, Arjomandy B, Kassaee A : The effect of androgen deprivation on the early changes in prostate volume following transperineal ultrasound guided interstitial therapy for localized carcinoma of the prostate. Int J Radiat Oncol Biol Phys, 44, 1107-1110, 1999.

(2005 年 10 月 25 日受付, 2006 年 3 月 15 日受理) 